\title{
MUSIIKIN SYNTAKSIN TUTKIMISEN KRITIIKKI JA PUOLUSTUS*
}

Musiikkikäsitteet - musiikkisysteemi - generatiivinen kielioppi • paradigmaattinen menetelmä • transformaatiot $\bullet$ temporaalisuus $\bullet$ semanttinen akkumulaatio $\bullet$ merkitykset $\bullet$ subjektiivisuus/objektiivisuus

Moderni etnomusikologia saa kiittää antropologiaa kolmesta perusideasta, joista on tullut nykyisen kuulonvaraisen ja kansanomaisen musiikin tutkimuksen kulmakiviä: kulttuurirelativismista, kenttätyöstä ja kulttuurista tietojärjestelmänä.

Kulttuurirelativismi, ajatus jonka mukaan jokainen kulttuuri on ainutlaatuinen ja ymmärrettävä omilla ehdoillaan, on peräisin Franz Boasilta. Kenttätyö eli ajatus että tutkittavaan kulttuurin on perehdyttävä omakohtaisen oleskelun ja tarkkailun avulla, on peräisin Bronislaw Malinowskilta. Kulttuurin ymmärtäminen opituksi, tiedolliseksi järjestelmäksi taas on peräisin ns. uudesta etnografiasta. Sen keskeisiä ajatuksiahan oli, että kieli ja kulttuuri ovat läheisessä suhteessa keskenään ja että edellisen tuntemus on avain myös jälkimmäisen ymmärtämiseen.

Erityisesti viimeksi mainittu idea on ollut etnomusikologiassa näkyvästi esillä. On nimittäin havaittu, että muusikot kansanomaisissakin kulttuureissa puhuvat musiikistaan ja käyttävät tässä yhteydessä tietynlaista fraseologiaa. Tämän fraseologian avulla ajatellaan voitavan johtaa tutkittavan

\footnotetext{
* Alkuluento Helsingin yliopistossa pidetyssä väitöstilaisuudessa 24.9.1988, vastaväittäjinä prof Eero Tarasti ja prof. Timo Leisiö ja kustoksena prof. Leea Virtanen.
} 
kulttuurin piilevä musiikkikäsitteistö, kirjoittamaton musiikinteoria. Tämän kansanomaisen musiikkikäsitteistön ymmärtämisen on katsottu olevan edellytyksenä myös itse soivan musiikin ymmärtämiselle. Äärimuodossaan ajatus on viety niin pitkälle, että joidenkin mielestä musiikkikäsitteistön analyysi voi suorastaan korvata perinteisen musiikkianalyysin.

Tähän sisältyy kuitenkin ristiriita, joka ei ehkä tule esille antropologisessa aineistossa, mutta joka on selvästi nähtävissä musiikissa. Jos antropologi tutkii esimerkiksi kasvien kansanomaisia luokituksia, vastakkain tässä ovat luonto itsessään ja toisaalta ihmisten käsitykset siitä. Kun taas etnomusikologi tutkii musiikkikäsitteitä, vastakkain on musiikki ihmisen luomana systeeminä ja toisaalta hänen sanallisesti iilmaisemansa käsitykset siitä. Vastakkain on siis kaksi tiedollista järjestelmää eli musiikki ja sitä koskeva puhe. Koska kumpikin on oma systeeminsä, ajatus että musiikkisysteemin toiminta voitaisiin paljastaa pelkästään puheanalyysin avulla, on heikosti perusteltavissa. Teesinäni onkin, että musiikkia koskevan puheen analyysi vaatii rinnalleen aina myös itse musiikkisysteemin analyysin.

Koska musiikki on systeemi, sen toiminnan selvittäminen edellyttää nähdäkseni kieliopillista lähestymistapaa. Olenkin työssäni esittänyt uuden generatiivisen kieliopin mallin, ja se on jatkoa lähinnä kolmen tutkijan eli Roman Jakobsonin, Constantin Brailoiun ja Nicolas Ruwet'n ideoille. Lähtökohtana on Jakobsonin ajatus, jonka mukaan kielellä poeettisessa funktiossaan on käytössä kaksi akselia, valinnan taso ja yhdistelyn taso. Yhdistelyn taso eli elementtien sijoittelu peräkkäin on Jakobsonin mukaan näkyvissä, "in praesentia" kun taas valinnan taso on olemassa vain piilevänä, "in absentia".

Romanialainen Constantin Brailoiu oli musiikintutkijoista ensimmäisiä, joka kykeni tuomaan kansansävelmistä esiin tämän "in absentia" -tason. Brailoiun idea oli saattaa saman kansansävelmän sisällä esiintyvä variointi näkyväksi kirjoittamalla saman laulun eri säkeistöt alekkain ja rekisteröimällä myöhtmmistä säkeistöistä vain muutoskohdat: näin nuotinnoksesta on luettavissa vaakatasossa yhdistely ja pystytasossa taas ne valinnaiset sävelkulut, joilla tietty kohta laulussa voidaan korvata.

Kun Brailoiun menetelmä kuvasi lähinnä varioinnin mahdollisuuksia, ratkaisevan askeleen kohti musiikin yhdistelyn tason eli sävelmien kieliopillisen rakenteen selvittämistä otti belgialainen kielitieteilijä Nicolas Ruwet. Hän kiinnitti huomiota musiikin identtisenä kertautuviin jaksoihin ja kirjoitti sävelmät paradigmaattisiksi ketjuiksi, joissa keskenään samanlaiset jaksot sattuvat aina alakkain.

Omassa generatiivisessa menetelmässäni olen kehittänyt näitä ideoita edelleen. Yhdistelyn tason kuvaamista olen laajentanut ottamalla analyysin apuvälineeksi puudiagrammit. Valinnan tason kuvausta olen jatkanut siten, 
että alakkain ei kirjoiteta pelkästään saman sävelmän eri säkeistöjä vaan kokonaan eri sävelmiä, joita kuitenkin yhdistää sama rakenne. Uutena käsitteenä on tuotu mukaan junktuuri, joka tarkoittaa elementtien välistä liitoskohtaa ja säätelee sitä, mitä elementtejä on lupa liittää toisiinsa. Uutta on myös se, että rakenneyksiköt on hajotettu melodia-, rytmi- ja harmoniasegmenteiksi, mikä mahdollistaa esimerkiksi saman melodiasegmentin pukemisen eri rytmisiin asuihin. Analyysin tuloksena onkin kieliopillinen kuvaus kohteena olevasta korpuksesta, joka mahdollistaa myös uusien tyylinmukaisten sävelmien rakentamisen.

Paradigmaattista menetelmää, jolle oma analyysitapanikin perustuu, on kuitenkin arvosteltu lähinnä kahdesta seikasta: siitä että se ei pysty kuvaamaan musiikin temporaalista luonnetta ja siitä, että se ei pysty tuomaan esille toiston kumulatiivista vaikutusta kuulijaan. Kritiikin asianmukaisuutta sopii kuitenkin hieman pohtia.

Mitä temporaalisuuteen tulee, musiikki on tietysti ajassa etenevää, jos asiaa tarkastellaan kuulijan kannalta. Toisaalta onhan kirjan lukeminenkin temporaalinen tapahtuma, jos asiaa ajatellaan lukijan kannalta lukukokemuksena - ja silti kirjallisuuttakin voidaan analysoida.

Temporaalisuuden ongelma musiikissa onkin lähinnä siinä, että kuulija ei hahmota musiikkia yhtenä kokonaisuutena vaan siitä aina pienen osan kerrallaan. Näin ajatellen musiikki on kuin syntagmaattinen ketju, joka tulee kuulijan toisesta korvasta sisään ja menee toisesta ulos; suoranaisesti havaituiksi tulevat vain ne yksiköt, jotka sillä hetkellä ovat pään sisällä. Mutta vaikka kuulija ei tätä ehkä itse tajuakaan, musiikki ei kuitenkaan ole pelkästään ketju toisiaan seuraavia elementtejä, vaan se on myös hierarkia, kerrosteisesti koostettu struktuuri.

Tämä havaitun ilmiasun ja taustalla piilevän struktuurin ero tulee selvästi esille esimerkiksi suomalaisissa pelimannisävelmissä. Jos yhden esityksen nuotintaa alusta loppuun - siis sellaisena kuin kuulija sen ottaa vastaan - nuottipaperia kuluu useampi sivu. Mutta jos sävelmässä esiintyvät lukuisat osien ja elementtien kertaukset taas jätetään huomiotta, sävelmä mahtuu paradigmaattisena nuotinnoksena puolikkaalle sivulle. Samalla alkuperäinen 80 elementin ketju typistyy ehkä kahdeksaksi elementiksi; loppu on yksiköiden eriasteista kertaamista ja sijoittelua taustalla olevan rakennekaavan mukaan.

Koska kuulija kokee sävelmästä vain pienen osan kerrallaan eikä näe itse kokonaisuutta, häntä voidaan huiputtaa: näinkään runsasta toistoa ei havaitse helposti toistoksi, koska se on kätkettyä. Totuus selviää vasta paperilla ja silloinkin vain paradigmaattisen analyysin kautta. - Kuulija voidaan siis hämätä, mutta paradigmaattista menetelmää ei.

Toinen paradigmaattisen analyysin kritiikki perustuu Jan Mukarovskyn 
ns. semanttisen akkumulaation teorialle. Sen mukaan jos meillä on ketju $a$, $b, c$ ja $d$, kuulija havaitsee ensimmäisen yksikön tavallaan puhtaana $a$ :na. Tätä seuraava $b$ nähdään kuitenkin edeltänyttä $a$ :ta vasten, $c$ nähdään $a b$ :tä vasten ja $d$ nähdään $a b c$ :tä vasten. Koska paradigmaattinen menetelmä kuvaa vain elementtejä ja niiden yhdistelyä mutta ei niiden semanttista kumulaatiota, kritiikki katsoo menetelmän olevan puutteellinen.

Mukarovskyn teoria on tietysti sinänsä oikea, minkä voimme havaita jos sovellamme sitä johonkin yksinkertaiseen tapaukseen. Tyyppiesimerkki kumulatiivisen efektin tehokkuudesta on ns. kiinalainen kidutus, jossa uhri sidotaan penkkiin, tippuvan vesihanan alle. Pisaroiden paradigmaattinen analyysi paljastaa, että tässä esiintyy vain yksi elementti, vesipisara, jota voidaan kuvata kirjaimella $a$; itse analyysi on loputon ketju alakkain kirjoitettuja $a$-kirjaimia. Vastaanottajan kannalta asia on toinen, sillä jokainen otsalle tipahtava pisara tuntuu entistä inhottavammalta eli pisaroiden vaikutus siis kumuloituu.

Pisaroiden syntaksi ja vastaanottajan reaktiot ovat kuitenkin kaksi eri asiaa, ja ne on pidettävä analyysissä erillään. Kritiikki unohtaakin sen, että paradigmaattisessa analyysissä ei ole tarkoituksena analysoida vastaanottajan reaktioita vaan musiikin syntaksin tasoa - tai musiikin neutritasoa, jos haluamme käyttää Jean-Jacques Nattiez'in termiä. Voimme jopa asettaa kyseenalaiseksi, onko musiikin syntaksin ja vastaanottajan kokemuksen samanaikainen analyysi edes mahdollista.

Musiikkitiede ja etnomusikologia näkevät asian kuitenkin hieman eri tavalla. Jos lähettäisimme musiikkitieteilijän tutkimaan pisaroiden semantiikkaa, hän luultavasti menisi itse hetkeksi vesihanan alle ja kirjoittaisi sen jälkeen kokemuksistaan - meidän kaikkien nimissä. Hän ei kuitenkaan katsoisi analysoivansa omia tuntemuksiaan, vaan niitä merkityksiä, jotka vesipisara itsessään esteettisenä objektina sisältää. Jos taas lähettäisimme paikalle etnomusikologin, hän menisi sinne nauhureidensa ja videoidensa kanssa tekemään "kenttätyötä". Tällöin hän yrittäisi tarkkailla, miltä penkissä hikoilevasta uhrista tuntuu - ja koettaisi ehkä jopa saada tältä jonkun sanallisen kommentin nauhalle

Kun musiikkitieteilijä pyrkii selittämään, miten asiat yleisesti ottaen ovat, etnomusikologi pyrkii selittämään, miten asiat ovat tutkittavan kulttuurin näkökulmasta, tämä kulttuurirelativismin oppeja noudattaen.

Kriittinen tarkkailija voi kuitenkin löytää sanomista sekä musiikkitieteilijän että etnomusikologin puuhista. Musiikkitieteellinen tapa on avoimesti subjektiivinen, etnomusikologinen tapa taas on näennäisen objektiivinen, mutta herättää silti loputtoman sarjan kysymyksiä: kuka on ihannevastaanottaja, mikä on ihannereaktio, mikä on havainnoinnin ihannekesto ja voidaanko tällaisella ulkoisella tarkkailulla ylipäänsä edes saada mitään 
merkittävää tietoa.

Paradoksaalista onkin, että musiikkitieteilijän subjektiivinen analyysi saattaa jossakin mielessä olla objektiivisempaa kuin etnomusikologin näennäisen "tieteellinen" metodi. Tämä johtuu siitä, että musiikkitieteilijä tarkastelee omaa kulttuuriaan sisältäkäsin yhtenä sen edustajana. Etnomusikologi taas, huolimatta siitä että hän yrittää tavoittaa kulttuurin "sisäistä" näkökulmaa, on kuitenkin aina jossakin määrin ulkopuolinen tutkimalleen kulttuurille.

Omassa työssäni olenkin luopunut vastaanottajapuolen merkitysten analyysistä. En halua kiistää, etteikö musiikilla olisi merkityksiä ja etteikö näitä voisi ainakin intuitiivisesti tutkia. Mutta koska tarkoituksena on ollut kehittää nimenomaan formaalisia musiikintutkimuksen menetelmiä, olen jättänyt vastaanottajapuolen rauhaan.

Silti puhtaalla musiikin syntaksin tutkimuksellakin on oma mielekkyytensä, ja käyttämäni paradigmaattinen menetelmä tuo musiikista tietoa, jota perinteiset analyysimenetelmät eivät ehkä kykene paljastamaan. Menetelmä

(1) auttaa ymmärtämään sävelmissä esiintyvää sisäistä variointia, joka tapahtuu paradigmaattisesti,

(2) se auttaa ymmärtämään transformaatioita ja uusien kappaleiden sepittämistä vanhojen pohjalta

(3) se auttaa ymmärtämään musiikkitekstin osien keskinäistä sidoksisuutta, toisin sanoen osien välisiä sukulaisuussuhteita, joiden nojalla tekstistä tulee yhtenäinen kokonaisuus,

(4) ja se auttaa ymmärtämään sävelmien muistamista; tämä tapahtuu paljastamalla toistuvat ja muistamista helpottavat rakennekaavat.

Ja asialla on myös soveltava puolensa, jos haluamme lainata antropologiasta vielä uuden idean vanhojen jatkoksi, nimittäin soveltavan tutkimuksen. Menetelmää voidaan hyödyntää paitsi musiikkisysteemien toiminnan kuvauksessa myös kansanmusiikin opetuksessa.

Koska menetelmä paljastaa piilevän "valinnan" tason, se avulla voidaan saattaa näkyväksi kansansävelmien varioinnin luvalliset rajat: millä kohtaa variointi voi tapahtua ja mitä sääntöjä se noudattaa. Niinpä paradigmaattisen notaation avulla esittäjä voi muunnella esitystään samaan tapaan kuin mitä kansanmuusikot kuulonvaraisissa esityksissään ovat tehneet.

Koska menetelmä mittaa sävelmän osien välistä sidoksisuutta, sen avulla voidaan haluttaessa suodattaa pois kappaleista niihin jälkikäteen sepitetyt ylimääräiset osat, jotka eivät ole kuuluneet kansanpelimannin alkuperäiseen "sävellykseen".

Ja koska menetelmä paljastaa sävelmäkorpuksessa elementtien yhdistely säännöt, sen avulla voidaan säveltää uusia sävelmiä kansanomaiseen 
tyliin. Tässä mielessä sitä voidaan käyttää apuna kansanmusiikin säveltämisen opetuksessa. Viimeksimainittu ei ehkä ole niin hassu idea, kuin miltä se ensikuulemalta vaikuttaa - ovathan kansansävelmätkin nimittäin aina jonkun tekemiä. Miksi niitä ei sitten voisi tehdä lisää?

\section{Lähteet}

Brailoiu, Constantin

1931 "Esquisse d'une méthode de folklore musical". Revue de musicologie 1931, 135. Julkaistu uudelleen: Constantin Brailoiu, Problemes d'ethnomusicologie. Toim. Gilbert Rouget. Geneve: Minkoff Reprint 1983, s. 5-35.

Casson, Ronald W.

1981 Language, culture, and cognition. Anthropological perspective. New York: Macmillan Publishers. 1981.

Jakobson, Roman

1981 "Linguistics and poetics". Teoksessa Roman Jakobson, Selected writings III. Poetry of grammar and grammar of poetry. Ed. by Stephen Rudy. The Hague etc. : Mouton Publishers. s. 18-51.

Mukarovsky, Jan

1976 (1940) On poetic language. Lisse: The Peter de Ridder Press.

Pekkilä, Erkki

1988 Musiikki tekstinä. Kuulonvaraisen musiikin analyysiteoria ja -metodi. Helsinki: Suomen musiikkitieteellinen seura. (Acta musicologica fennica 18).

Ruwet, Nicolas

1966 "Méthodes d'analyse en musicologie." Revue Belge de Musicologie 20 (1966), 65-90. Julkaistu uudelleen: Nicolas Ruwet, Langage, musique, poési. Paris: Seuil. 1972, s. 100-148.

Steiner, Peter and Wendy

1976 "Postcript. The relational axes of poetic language". Teoksessa Jan Mukarovsky, On poetic language, Lisse. s. 72-86.

Tarasti, Eero

1986 "Devenir". Teoksessa A.J. Greimas \& Joseph Courtés (éd.), Sémiotique. Dictionnaire raisonné de la théorie du langage II. Paris: Hachette. s. 67-68. 


\section{Summary}

\section{Critique and defence of the study of musical syntax}

A recent trend in ethnomusicology has been the study of musical conceptualizations; in its extreme form, this implies the premise that it is not the music itself but speech about music that is of primary importance on the study. Although both music and speech are humanly organized modes of expression, they are nevertheless two separate modes of communication, which makes it necessary to study not only speech but music as well.

The study of music in itself should examine it as a system. This is because each musical tune is composed of certain elementary units which are part of a hidden structure. It is the task of the analyst to single out the constituent units and seek to establish a grammar to describe them, i.e. to lay bare their axes of selection and combination. The former can be done by writing all structurally identical tunes one below the other, where the axis of selection is to be read vertically; the latter by noting how the elements are connected to each other, via the use of tree diagrams and the concept of "juncture". These procedures will lead us to a grammar of tunes.

Criticism of the paradigmatic analysis has pointed put two facts: first, that the method does not bring out the temporal nature of music, i.e. that music is a constant flow on a time axis; and second, that it does not take into account the cumulative effect that repeated passages have on the listener. This view, however, is based on false assumptions and on an inadequate understanding of the method.

As regards temporality in music, we may say that the only problem here is that a listener never perceives music as a whole but only a small portion of it at a time. This prevents him from seeing the structural framework underlying a tune, a framework which can be unfolded only with the help of a paradigmatic and structural analysis.

The second point of criticism is that the method ignores the cumulative effect of reiteration, a theory originally proposed by the Czech semiotician Jan Mukarovsky in the 30's. Although Mukarovsky is probably right, especially in simple cases like "Chinese torture" with water drops falling steadily on the victim's forehead, the critics fail to see that the aim of a paradigmatic method is not to describe the reactions of the recipient but instead the syntax of the music. The syntactic and semantic levels are two separate things and should not be confused.

Such misunderstandings may arise from the fact that historical musicology and anthropological ethnomusicology are based on two 
separate scholarly traditions. Thus while a musicologist would aim at describing how things are generally speaking, an ethnomusicologist would try to describe how things are in a given culture. And while a musicologist would base his judgments on his own intuitions, an ethnomusicologist would base them on observation of how the members of a culture conceive things. Being intuitive in nature, musicological observation could be also regarded as subjective. But on the other hand, the musicologist's way of seeing things may in a certain sense be more objective than that of the ethnomusicologist. This is because the musicologist looks at his own musical culture from the inside and the ethnomusicologist from the outside, as an alien to the culture he studies.

Owing to these interpretative problems, it makes some sense to concentrate only on the musical syntax and ignore the semantic aspects of music. However, even the study of musical syntax alone is useful in many ways. It helps us to understand 1) how internal variation, which is always present in folk tunes, takes place; 2) how performers transform and mold old tunes, and build up new tunes from them; 3 ) how the bonds between elements of different stanzas in a tune are formed; 4) and how performers are able to keep a great number of tunes in their memory.

The use of the generative method for applied purposes has its points, as well. Since the method may reveal the hidden axis of selection, the performer will be able to vary his performance in more or less the same way as folk musicians originally did. Since it unfolds the bonds between different stanzas of a tune, the stanzas that have been added afterwards to an original composition may be filtered out. And since the method gives taxonomy of the constituent units and a grammar of their combination, it will enable us to compose new tunes in the original style, where nobody can tell the difference between an "original" and a "generated" tune. 